\title{
Deficiencies of Eye Contact and Face- to-Face Interactions in Social Relations Among Children with Autism
}

\author{
Barbara Winczura
}

University of Wroclaw, Department of Historical and Pedagogical Sciences, Institute of Pedagogy, ul. J. W. Dawida 1, 50-527 Wrocław, Poland, basiawa@wp.pl

\begin{abstract}
Ability to read information from human face is compelling for social communication as it enables to understand emotions experienced by other persons, their intentions and needs, what in turn can allow to predict their behaviour, hence it is one of the first stages of developing knowledge on other people. As the research and observations prove, from very early stage of growth the infants realise that a human face is an object of crucial meaning. While entering face-to-face interaction and establishing eye contact they learn convictions of mental and social lives of others. Problems with social communication of children with autism, particularly in terms of eye contact and looking at the partner of an interaction, allow to distinguish children with autism from their peers with other developmental disorders. Children with autism observe people less, and if they do, they do not concentrate on their faces. Moreover, they are not interested in what others express while establishing eye contact, hence not reading their facial expression nor recognising emotions noticeable from face. On top of that, they do not react, or react with delay to the stimuli, avoiding direct eye contact. Therefore, they are unable to read the intention of the direction or expression of the eye contact as a tip useful in interpreting others' behaviour, and since children with autism do not understand the meaning of information contained within facial expression and eye contact, their range of social experiences during conversation is significantly limited. It profoundly affects their social communication with other people, particularly as far as initiating and maintaining interactions are concerned.
\end{abstract}

Keywords: autistic child, eye contact, face-to-face interaction, social relations, social communication. 


\section{Introduction}

Social and developmental psychologists claim, that communicating by the means of any possible methods, tools and ways of exchanging information is fundamental for social interactions. They also promote the idea, that people's social behaviour is feasible thanks to communication itself, whereas the primary inability to establish emotional and social contact, including the eye contact and looking at the parent, is one of the most frequently occurring autism deficiencies (Kliś, 1994). Lack, or limited eye contact, is often referred to as "an empty" look. Autistic children are hardly interested in human face, the sight and voice of their mother (Błeszyński, 2011; Senator, 2006), not fixing eyes on her face, nor following her with eyes. Their sight roams in the space, not reacting emotionally at her gaze, smile or gestures (Jaklewicz, 2000). The disturbed face mimicry is specified by the "mask look", lack of warm, jolly expression accompanying the gaze along with typical inability to take an attitude expressing readiness and desire to be held in arms (Wing, 2005). Social smile is rare, sometimes looking artificial, as if glued (Pisula, 2005), however accompanying short periods of looking at people is reported (Randall, 2010). Taking into consideration that such abilities and behaviours initiate all types of social interactions, it seems justified to analyse the research results concerning the gaze behaviour, including the process of establishing eye contact with reference to autistic children.

\section{Eye contact as a source of establishing social and intentional relations at early stages of ontogenesis}

The infants come to the world with given mental dispositions and sometimes even tendencies of selective reacting to some, given stimuli and ability to structure their responses. It is particularly striking how both perception as well as tendencies to react are pre-adapted to mediate in the infant's integration with the social surrounding. Longitudinal observations and research justify that infants posses surprisingly good perceptive skills and are particularly sensitive and generally related to other people (Schaffer, 1994). The research tackling the first mother-child interactions stresses, that a healthy infant is "equipped" with sensitivity and ability to adapt to social circumstances, especially in terms of synchronising interactions and searching for the eye contact as a response to mother's voice (Jagielska, 2009). Several experiments confirmed that as early as from the birth, infants prefer human faces, reacting to their gaze or similar objects, being able to adjust to own caretaker (Butterworth, 1997). The very first contact between a mother and her baby after it is born sets an example of face-to-face interaction, when a mother takes her child in her arms constantly looking at her baby (Cieszyńska, 2008).

The sight of a human face is an unconditional stimulus for the infant (Kliś, 1994), and, looking at other human face is an essential phenomenon and a manner of gathering knowl- 
edge on own caretaker. Remembering faces of other people and this what we know about them, constitute key premises for social development of each individual (Frith, 2008).

"Some people have it all written all over their faces" is a well-known saying, indicating the function of a face as a carrier of interpersonal communication. Face of other human is also a source of information on his / her emotional state, as mimicry supports understanding verbal signals, often even replacing it (Urbaniuk, 2009). Direct, face-to-face contacts constitute essential context for social interactions, enabling infants to become familiar with adults' physical features and to master the art of adjusting own behaviour to the behaviour of others (Schaffer, 1994).

The issues related to the facial perception meets with great interest of developmental psychologists, with one of the most surprising discoveries that the sight of a face, the real one or an image, attract infants' attention to a large degree. Despite poor sight, the infant can recognise mother's face as early just few hours after being born (Walton, 1992; Morton, 1991; Przetacznik-Gierowska, 1992) Early recognition of faces is probably related to cortical or subcortical structures such as superior culiculli or amygdaloidal nucleus. Processing information within facial expression involves many cortical areas located in prefrontal, occipital and other temporal areas. Nonetheless, so far their role has not been thoroughly examined (Jaśkowski, 2009).

In one of the experiments newly born, one-day children were shown two photos on a video, one presenting the child's mother, the other showing a strange woman of similar skin colour and hairdo. The infants' reactions were measured on the basis of the pace of sucking a special dummy connected to the video recorder. If a child sucked the dummy fast, it held the image of currently presented face on the screen. Almost each of the infants accelerated the pace of sucking in order to have their mother's face presented in front of them. Some infants even preferred to watch father's face than other man, as long as their prior contacts were long enough (Eliot, 2003; Gopnik, 2004).

Contemporarily, it is a common consensus that it is not the face itself that draws attention, but rather a set of simplified features that are typical for human face such as density of angles, complexity, three-dimensionality and mobility. Each of these qualities itself deserve the attention, but their combination (as manifesting in real faces) implies that a parent becomes extremely distinguished source of stimuli to a child (Schaffer, 2004). It is partly caused by the fact that infants manifest visual attraction to the responses to stimuli with shapes resembling a face. Therefore, they prefer to look at a set of dots and lines resembling human face, i.e. an oval figure with eyes, nose and lips marked in the right places, rather than to observe other geometrical layout or faces presented upside down. As early as after their birth, infants begin to rotate their heads and turn eyes following sketches of face, rather than to follow equally simple picture with blurred details of a face. It sets an example of a phenomena understandable from the evolutionistic point of view, as it proves that the infants posses the disposition to turn towards their mothers, what probably tightens their mutual bond (Eliot, 2003; Jaśkowski, 2009). 
Such early attractiveness of face-to-face interaction make infants in their further growth attracted to other features of the partner, particularly those that distinguish people among each other. At the age of 7-8 months, children begin to distinguish between unknown and familiar faces, manifesting fear of strangers and quickly learning to distinguish between man's and woman's face (Schaffer, 1994) (Urbaniuk, 2009). During the first 9 months of their lives, infants can distinguish the expression of joy, sorrow and anger, as well as even associate that a jolly face - smiled one with squinting eyes - matches jolly tone of the voice. Many researches confirmed that infants prefer human faces and voices, distinguishing them from the majority of perceptive stimuli of other kind. Moreover, they are capable of spotting subtle differences between faces (Meltzoff \& Kuhl, 2004; Sherrod, 1981) and voices (DeCasper \& Spance, 1986). Besides, they can sense the over-modal relation between voices and faces (Taylor, 2007). For instance, children can be simultaneously shown two films, one with a jolly face and the other with a sad one. If such projection is accompanied by a jolly or sad voice, the infants will take closer and longer looks at their faces expressing adequate emotion appropriate to the voice they hear (Walker-Andrews, 1997).

The infants not only distinguish and prefer human faces, but are probably able to realise that these faces "resemble" their own, hence there is nothing more integral than such internal experiencing of own body, movements and expression. From the day of the birth this deeply personal sensation is related to the movements of other people's bodies, which we can only see, and not directly experience. It may be colloquially concluded that the mother nature was very smart to give us a sense that allows to understand other minds, what subsequently leads to the awareness that we are as other people, and they are like us (Gopnik\&Meltzoff, 2004; Meltzoff \& Kuhl, 2004; Meltzoff \& Gopnik, 2003).

Even the limited infants' vision makes them pay particular attention to people. Such small babies are extremely short-sighted and contrary to adults they have problems with accommodation when they observe close and distant objects. However, these objects which are $30 \mathrm{~cm}$ away are clearly visible, whereas those located further or closer than this distance are blurred. It sets an example of an excellent construction, as this the exact distance from the infants' face to the face of person holding them in their arms. It s not something learned, but a natural way in which mothers keep their faces during interaction with their babies. Infants are simply "constructed" in such way to see more clearly those, who tend and take care of them (Meltzoff\&Kuhl, 2004; Butterworth, 1997).

Another milestone in the social and emotional development takes place when an infant begins to smile at other people, which periodically corresponds with its 6th week of life. It is the time when infants respond with a smile to their mothers' smile, however these are not the very first grins, as such babies smile from their birth every now and then, with the difference that before this stage they smile with their corners of the mouth and open mouth what takes place rather unintentionally, unrelated to any situation, given emotional conditions or stimulation of the neurons in the brain stem. On the other 
hand, sociable smile emerges in all cultures between the 4th and 6th week of life, when children smile at specific social signals as a gaze, eye contact, mother's voice or gentle stroking (Eliot, 2003).

Around their 8th week of life infants orientate notably more intense towards external surrounding, predominantly due to a rapid growth of vision ability. As a result, their attitude and behaviour towards other people change, with the emergence of direct eye contact with a partner. It justifies prolonged periods of gazing and first smiles provoked by the surrounding. Examining the gaze of 30 month-old infants towards their mothers in the situation of face-to-face contact, D. N. Stern confirmed that the intervals ratio between given sequence of a gaze is characteristic and individual for given infant, as if it was biological, genetically determined pattern The only aspects that altered depending on interest arouse by the mother, was the ratio of looking at, and turning the look back from their mothers (Schaffer, 1994).

Sometimes compulsory gazing at mother's face and exchange of intensive looks make parents convinced that there is a bond between them and their child, therefore long eye contact is probably significantly connected to this feeling. Therefore, social interactions occur predominantly within the context of face-to-face contacts, whereas regulation of mutual attention and responses become the main developmental issue for a child and the adult. A mother looks at her baby for a long period of time, always ready to response to any sort of signal of attention from the baby, anticipating to adjust her behaviour to baby's expectations. By doing so, such mother provides a framework within which child's gaze enters a two-sided cycle, i.e. from and to. The child's gaze is initially restricted by biologically determined borders that regulate the exchange of the periods of looking and not looking at the objects, and at this stage infants do not express flexibility and intentionality of the gazes typical for older children's looks. Mothers seem to be almost always ready to establish eye contact, however whether the interaction shall, or shall not occur, overwhelmingly depends on the child. It is more likely that the mother will look at the child first and the child will not return this gaze. However, as far as mothers are concerned, it is highly probable that they will continually undertake efforts to adjust to child's frequency and intensity of stimulation provided during such episodes while helping their child to sustain optimal level of stimulation and interpreting the infant's gazes as a signal to cease or minimise it.

Turning back the gaze of an infant in a situation when a mother continues to gaze for too long sets one of the examples of modulating the level of such stimulation, as it may be too stimulating experience for a child. However, it seems that mothers are very cautious in face-t-ace contacts with their children, hence they are able to regulate the frequency of such interactions. Mutual gazes provides example of early face-to-face interaction, what is acknowledged by the fact that at such early stage it is possible for some "equality" to remain within dual relations between a child and an adult (Schaffer, 1994). There are many opportunities for face-to-face interactions encouraging mothers and children to 
establish contact. Moreover, it enables parents and caretakers to carry out attentive observation of the behaviour and reaction of their child along with their process of learning typical cycles of vigilant attention, and on the other hand, activity towards avoidance and calmness. Discovering such cycles is particularly important for comprehension of social interactions at early stage of child's development (Cieszyńska, 2008).

Fascination with human faces typical for early months of infants' life constitutes a predicator for the abilities to understand and read nonverbal information from the face map. Moreover, as the research results imply, from the early beginning the children realise that other people are objects of great importance in their lives. Hence, we may conclude that such early fascination with human face, mutual face-to-face interactions and establishing eye contact may be directly related to the development of convictions on mental and social life (Taylor, 2007).

\section{Deficiencies in eye contacts and face-to-face interactions in children with autism}

In case of small children with suspected autism, parents, who establish contact with such child, are able to spot signs of indifference from stage of infancy. They report that their children rarely fix their eyes on given person deliberately or intentionally look straight into their mothers' eyes. They are never sure whether their child's gaze is set inward or towards the external objects. It is equally hindered to state what they are focused on any given moment, or what happens in their minds and what kind of emotions they experience. Despite the fact their mothers often keep their gaze on them for longer period of time literally staring into their faces, smiling or singing to them, they get the impression that it is not reciprocated. The children's gaze seems to be roaming around their mothers' look, seldom and accidently fixing on them. Children with autism do not focus their attention on any object for too long and too intense, and there are particularly uninterested in looking at a speaking person. They rather seem to perceive people and the surrounding by the use of peripheral scope of vision, and it is often referred to as empty, "glass" gaze as far as children with autism are concerned. In the course of ordinary two-sided interaction, they are incapable of becoming an appropriate counterpart for their partners, hence they do not need the facial expression as a tool to set up such contact. Their gaze is sometimes tense, whereas when they speak, their faces are usually blank and saggy, what appears to be matching such lost, absent gaze. Therefore, expressional functions of the face responsible for establishing social contact are handicapped (Asperger, 2005).

Difficulties in maintaining eye contact, insufficient and inadequate regulation of the attitude and facial expression in the context of given social situation, as well as lack of reaction to the gaze of a familiar person are among features typically associated with symptoms of autism (Pużyński \& Wiórka, 1998). There are some conjectures that children 
with autism do not remember faces nor buildings or landscapes. There are also hypotheses implying they are affected by a kind of "blindness to people" or "face blindness". R. Schultz et al. (2000) researched that the area of brain that is responsible for processing information concerning faces (i.e. cerebral fusiform sulcus) does not reveal such activity among children with autism. On the other hand, their inferior temporal cortex reports activity, whereas among healthy children it remains active solely in the course of processing the images of objects (things). As a result, objects and faces are processed by autistic persons in similar manner (Jagielska, 2009). Such disorders disable small children with autism to look at the faces of their caretakers or parents (predominantly mothers).

It is also probably related to the difficulties in recognising familiar faces by the children. Disorder of such type is referred to as prosopagnosia, which means that a child sees particular elements of a face such as the nose, ears, or eyes but has problems with recognising configuration of these elements upon next encounter with such person. Difficulties in identifying face may be accompanied by other symptoms such as disordered perception of places and inappropriate interpretation of the mimicry and emotional expression. Hence, a child not looking at a face does not have to undertake the attempt to recognise it, as reception of the stimuli of the face requires to carry out analysis of the stored information concerning it along with adequate information memorising.

Face constitutes a combination of figures, and although children with autism distinguish figures, paradoxically prosopagnosia does not imply disturbances related to recognising figures, patterns or objects of everyday use. Recognising faces requires to conduct analysis and synthesis of the perceived elements and their comparison with previously seen and remembered faces. Essentially, it is necessary to acknowledge that the perceived set of figures constitutes a face, and then identification should take place involving the procedures of matching or memorising. In case of autistic disorders it is still unknown which of the stages of face recognition is disturbed, i.e. whether it tackles integrating new data with the old one, memory processes, attention or its influence on given behaviour. It should also be taken into consideration that the phenomena of recognising faces is affected by perceptive difficulties causing procrastination of the reaction (similarly as in the case of echolalia mechanism) (Urbaniuk, 2009; Pietz \& Ebinger, 2003; Barton et al., 2004).

J. Pietzi, F. Ebinger (2003) carried out research on a boy aged 4 years 11 months with Asperger syndrome and prosopagnosia using Kauffman Assessment Battery for Children (K-ABC) test in the diagnosis. Standardised norms of this tests allow to examine children as early as in their 30th month of life with one of the subtest analysing recognition of human faces. Such child becomes familiar with one or two photos (5-second exposition), and the seen faces are subsequently recognised during next exposition. The researched boy did not recognise his closest relative from family pictures (his mother and father); however, in the room where the examination took place, he was able to point where his mother and father were sitting (Urbaniuk, 2009). Concurrently, no other problems with 
recognising geometrical figures were reported. The result of the recognition of faces subtest provided lowest level achieved by this patient. As far as other subtests of the K-ABC are concerned, this boy's results were average. Hence, it was the only subtest where his dysfunctions emerged. Nonetheless, it must be added, that in case of developmental prosopagnosia, Asperger syndrome is often considered as the most typical example. Such patients possess higher communicative skills and are able to cooperate during the research, what enables the verification of many more hypotheses during the diagnostic process, comparing to other disorders of this category. Description of individual cases does not allow to generalise, but implies a suggestion to analyse children's behaviour from the perspective of prosopagnosia in the context of diagnosis and observation of children with autistic syndrome (Urbaniuk, 2009).

The experiments conducted by S. J. Hutta et al., recorded time in which autistic children take look at the pictures of faces. The selection of faces included happy and sad ones, as well as empty oval with neither features nor traits. Most of the researched children spent more time on looking at the last picture, however it seemed as if the two other images were unnoticed by them, passed by indifferently. It may provide the proof that autistic children recognise faces only as geometrical figures, as if almost fascinated by them (Olechnowicz, 1995). Results of these experiments are contradictory to the research among children of appropriate development. R. L. Fantz revealed experimentally that the researched infants prefer facial expressions with regular features and focus their gaze on them longer than on the black-and-white ones, with oval picture not presenting a human face at all (Przetacznik-Gierowska, 1992).

Noticing face which eyes are fixed on us automatically draws our attention. In one of the research by L. Conty and his team the research participants were shown pictures of few faces. The researched quicker and more precisely spotted the face with eyes looking straight at the observer rather than faces with other direction of the gaze.

A. Senju and T. Hasegawa proved that the stimuli detection beyond the vision sphere was more difficult if a face with gaze straight within such sphere of sight emerged. Attracting attention by the face looking into the observer probably results from social significance of the visual contact (Jaśkowski, 2009). Moreover, P. I. Mirenda carried out research aiming to determine the frequency and duration of the child's gaze at the interaction partner. The experiment was carried out among children of appropriate development and those with autism. It turned out that the general time of healthy children's gaze at interaction partner was comparable to the result of children with autism. The differences were mainly indicating that in a situation of monologues the autistic children's expressed tendencies to look at the interlocutor's face longer and more frequent that the healthy children. The opposite situation took place in dialogic contact, and despite the fact that none of the reported differences turned out to be statistically irrelevant, the author of the research suggests that the difference in establishing face-to-face interaction by autistic children in comparison to appropriately developing children is rather of qualitative, not 
quantitative character. Hence, it is not about the number of gazes into interaction partner, but about the way of looking at the interlocutor's face by children with autism (Kliś, 1994).

As it may be concluded from the research, children with autism observe people less and shorter, and if they do, they do not concentrate on their faces, as they definitely prefer still stimuli, regardless of the fact whether such stimuli are in move or stand still (Pisula, 2010).

The clinical observations provide with conclusions that about 2 nd year of life a significant abnormality within establishing eye contact may occur among children with autism, including absent, fleeting gaze, furtive look or gaze out of the corner of the eye looking at those who are not reciprocating such gaze given moment, looking "through" person with the gaze suspended in the space, persistent stare into the eyes or other element of a face, irregular, short gaze when the children want something, or when something draws their attention, and last but not least - establishing eye contact only with those most familiar from the closest surrounding (Siegel, 1996), (Kruk-Lasocka, 1994). It may also happen that children with autism will be suspected of profound vision impairment as they move their hands in front of their eyes as profoundly visually impaired children (Jagielska, 2009).

J. Sterling and G. Dawson proved that on the basis of video films made during first child's birth, babies with autism can be distinguished from the health ones considering symptoms typical for autism. The main differences embraced eye contact, directing gaze towards person calling the child by name, as well as while indicating, pointing or passing on the subjects. Children with autism differed within this range from those 8-10 month-old infants developing appropriately and in comparison to 12 month-old babies with developmental impairment. The authors stress that not looking at other's faces and lack of eye contact was the main, single autism indicator. On the other hand, the analysis of recordings carried out by J. L. Adrien at al. during the second year of children's life revealed that children with autism more often ignored people, preferring isolation and avoidance of eye contact. Such symptoms at this age were expressed far more significantly that among infants (Pisula, 2005). Moreover, characterising social disturbances noticeable in small children's behaviour, W. L Stone (Stone, 1997) particularly emphasised lack or limited eye contact.

Looking into the other person's eyes often remain unrelated to the fact of talking to someone. It turns out that the ability to establish eye contact develops along with age (Pisula, 1993). P. Mundy, C. Kasari, and M. Sigman reported that among children aged under 20 months there were deficiencies within eye contact, whereas in case of those over 20 months of mental age no disturbance in eye contact were reported (Pisula, 2002). It seems crucial that these abnormalities in the course of interactions are particularly significant among small children or those mentally underdeveloped. The research conducted by R. Cordes on the specificity of early interaction of baby and mother embraced 10 babies average 16 months of age with the control group of 10 autistic children average 
36 months of age and 15 months of mental age, and proved that the visual reaction to mother's call among autistic children occurred delayed and was in its duration inadequate to the situation (Kruk-Lasocka, 1994).

Older autistic children, or those with higher IQ, far more often enter the eye contact. Results of some research prove that in quantitative manner such children establish eye contact as often as children developing appropriately. However, it does not imply that they do so adequately to the situation. W. Phillips, S. Baron-Cohen, and M. Rutter (Pisula, 2005) carried out an experiment where a therapist encouraged the child to play with attractive toy and when the child was engaged in the game, the psychologist aborted it, holding child's hands. Most of the appropriately developing children or with mental disability would look at the therapist with puzzlement, whereas the children with autism would look at their hands, the toy or tried to free themselves.

According to J. Richer and R. Cross any kinds of deviation in establishing eye contact accompanying this group of children is related to the degree of their nervous stimulation, whereas its avoidance is linked by the authors to excessive stimulation and desire to reduce the too high level of activation. On the other hand, L. Wing assumes, that disturbances with this regard are caused by specific defect in the mechanisms of understanding the surrounding by autistic children, what in turn generates avoidance of too burdening stimuli. Such a defect is, as the author claims, caused by a damage in the central nervous system, what consequently hinders the process of coding stimuli and shaping notions, leading to emergence of the set of avoidance behaviours. Therefore, eye contact with partner's face provides children with insufficient information, becoming at the same time stimuli not rewarding enough. In such case children less and less often look at the partner's face, what subsequently makes access to number of new information hindered and infrequent (Kliś, 1994).

According to S. Baron-Cohen and P. Balton research (Baron-Cohen, 1998), children with autism gaze at objects for shorter period of time rather than avoid the eye contact. Such period is particularly shorter as far as looking straight into the eyes is concerned. It may give the impression that such children avoid eye contact, however in fact it, is not as intentional as some scientists suppose. It seems that children do not understand how to use eye contact to communicate without words or how to read faces of other people. It is difficult for them to interpret signals at such level, including situations and expressions such as "the looks kill" "to soften the heart" or "to attract attention". They are unable to understand that a gaze reflects to some degree the internal condition of people around, not only their behaviour at any given moment. From such perspective, the exchange of gazes for autistic child is of very little importance. It proves that these children very often simply omit exchange of looks and do not understand that the eye contact may be a carrier of information regarding social communication. They seem to be uninterested in establishing eye contact and looking at people's faces in order to read their needs, desires and intentions, hence it seems not understood to them that state of 
mind shared by the persons is reflected in the gaze (Frith, 2008). Therefore, for children with autism, that do not understand the state of mind determining such types of gaze, the eye contact is irrelevant and does not manifest communicative, social nor intentional function (Baron-Cohen, 1995).

F. Volkmar with his team concluded his research that any disturbances in establishing eye contact result from lack of interest in social surrounding and difficulties in processing information of social character. Moreover, he proved that eye contact can vary depending on the structure of the environment, expressed by the proportion of the caretaking staff and the children themselves. In more structured surroundings the eye contact was more frequent and adequate to other behaviours (Pisula, 1993). Many authors including R. V. Exline, I. C. Winters, C. Hutt and C. Qunsted prove that avoiding eye contact by an autistic child occurs usually along with number of other symptoms typical for this group of children, such as emotional withdrawal from the contacts, unwillingness to establish emotional relation with others and mood swings. The recalled authors claim that functioning of a child with autism as if "from the distance", impersonal or isolated form, is caused by the lack of primary ability to fix gaze on human face in order to read crucial information and understand social behaviours of other people (Kliś, 1994).

Disturbance in social communication, particularly in terms of eye contact and reading mimicry, allow to distinguish children with autism from their peers with other developmental difficulties, especially that such problems emerge early in the course of development (Pisula, 2010). All forms of avoiding gazes, not establishing eye contact, and lack of readiness to look straight into the face of interaction partner, may be prolonged to as late as the school age in children with autism, consequently becoming a serious obstacle to adapt to the adult life in the future (Rapin, 1991).

\section{References}

Asperger, H. (2005). Psychopatia autystyczna okresu dzieciństwa. In U. Frith (Ed.). Autyzmizespót Aspergera (p. 87). Warszawa: Wydawnictwa Lekarskie PZWL.

Baron-Cohen, S. (1995). Mind blindness: An essay on autism and theory of mind. London: MIT Press.

Baron-Cohen, S., Balton, P. (1999). Autyzm - Fakty. Kraków: Krajowe Towarzystwo Autyzmu. Barton, J. J. S., Cherkasova, M. V., Hefter, R., Cox, T. A., O’Connor, M., \& Manoach, D. S. (2004).

Are Patients with social developmental disorders prosopagnosic? Perceptual heterogeneity in the Asperger and socio-emotional processing disorders. Brain, 127.

Błeszyński, J. (2011). Autyzm a niepełnosprawność intelektualna i opóźnienie w rozwoju .Skala Oceny Zachowań Autystycznych (p. 61). Gdańsk: Harmonia Universalis.

Butterworth, G. (1997). Niemowlęctwo. In P. E. Bryant, \& A. M. Colman (Eds.). Psychologia rozwojowa (pp. 21, 24). Poznań: Zyski S-ka Wydawnictwo. 
Cieszyńska, J., \& Korendo, M. (2008). Wczesna interwencja terapeutyczna. Stymulacja rozwoju dz iecka. Odnoworodka do 6 rokużycia (p. 229). Kraków: Wydawnictwo Edukacyjne.

DeCasper, A. J., \& Spance, M. J. (1986). Prenatal maternal speech influences newborns' perception of speech sounds. Infant Behavior and Development, 9.

Eliot, L. (2003). Co tam siędzieje? Jak rozwijasię mózgiumysł w pierwszych pięciu latach życia (pp. 301, 411). Poznań: Media Rodzina.

Frith, U. (2008). Autyzm. Wczesna interwencja terapeutyczna. Stymulacja rozwoju dziecka. Odnoworodka do 6 rokużycia (p. 134). Gdańsk: Gdańskie Wydawnictwo Psychologiczne.

Gopnik, A., \& Meltzoff, A. N. (1994). Minds, bodies, persons: Young Children's understanding of the self and others as reflected in imitation and theory of mind research. In S. T. Parker, R. W. Mitchell, \& M. L. Boccia (Eds.). Self-awareness in animals and humans. New York: Cambridge University Press.

Meltzoff, A. N., \& Kuhl, P. K. (2004). Naukowiec w kołysce. Czego o umyśle ucza nas małe dzieci (pp. 44, 45, 46). Poznań: Media Rodzina.

Jagielska, G. (2009). Objawy autyzmu dziecięcego. In J. Komender, G. Jagielska, \& A. Bryńska (Eds.). Autyzm i zespół Aspergera (pp. 36, 38). Warszawa: Wydawnictwo Lekarskie PZWL.

Jagielska, G. (2009). Etiologia zaburzeń autystycznych. In J. Komender, \& G. Jagielska, \& A. Bryńska (Eds.). Autyzmizespół Aspergera (p. 30). Warszawa: Wydawnictwo Lekarskie PZWL. Jaklewicz, H. (2000). Autyzm dziecięcy. In A. Popielarska, \& M. Popielarska (Eds.). Psychiatria wieku rozwojowego (p. 188). Warszawa: Wydawnictwo Lekarskie PZWL.

Jaśkowski, P. (2009). Neuronauka poznawcza. Jak mózg tworzy umysł (p. 239). Warszawa: Vizja Press \& It.

Pużyński, S., \& Wiórka, J. (1998). Klasyfikacja zaburzeń psychicznych i zaburzeń zachowania w ICD-10. Badawcze kryteria diagnostyczne. Kraków, Warszawa: Uniwersyteckie Wydawnictwo Medyczne.

Kruk-Lasocka, J. (1994). Autyzma Oligofrenia. Szkoła Specjalna, no. 4.

Kliś, M. (1994). Deficyt kontaktów wzrokowych w interakcjach społecznych dzieci autystycznych. In Wł. Dykcik (Ed.). Autyzm, kontrowersjei wyzwania (pp. 69, 72, 73, 75). Poznań: Wydawnictwo Eruditus.

Meltzoff, A. N., \& Gopnik, A. (1993). The role of imitation in understanding persons and developing a theory of mind. In S. Baron-Cohen, \& H. Tager-Flusberg, \& D. J. Cohen (Eds.). Understanding other minds: Perspectives from autism. New York: Oxford University Press.

Morton, J., \& Johnson, M. H. (1991). Conspec and Conlern: A two-process theory of infant face recognition. Psychological Review, 98.

Olechnowicz, H. (1995). Dziecko własnym terapeuta. Warszawa: Wydawnictwo Naukowe PWN.

Pietz, J., \& Ebinger, F. (2003). Prosopagnosia in a preschool child with Asperger Syndrome. Developmental Medicine and Child Neurology, 45.

Pisula, E. (1993). Autyzm - fakty, wątpliwości, opinie. Warszawa: Wyższa Szkoła Pedagogiki Specjalnej. 
Pisula, E. (2002). Czego wciąż nie wiemy o autyzmie? In J. Rola, \& M. Zalewska (Eds.). Wybrane zagadnienia z psychologii klinicznej dziecka (p. 12). Warszawa: Wydawnictwo Akademii Pedagogiki Specjalnej im. Marii Grzegorzewskiej.

Pisula, E. (2005). Małedziecko z autyzmem, diagnozaiterapia (pp. 32, 48, 71). Gdańsk: Gdańskie Wydawnictwo Psychologiczne.

Pisula, E. (2010). Autyzm. Przyczyny, symptomy, terapia (p. 44). Gdańsk: Wydawnictwo Harmonia. Przetacznik-Gierowska, M., \& Makiełło-Jarża, G. (1992). Psychologia rozwojowa i wychowawcza wieku dziecięcego (pp. 97, 175). Warszawa: Wydawnictwa Szkolnei Pedagogiczne.

Randall, P., \& Parker, J. (2010). Autyzm jak pomóc rodzinie (pp. 99, 146). Sopot: Gdańskie Wydawnictwo Psychologiczne.

Rapin, I. (1991). Autistic Children: Diagnosis and Clinical Features. Pediatrics, 87, 5.

Schaffer, H. R. (1994). Wczesny rozwój społeczny. In A. Brzezińska, \& G. Lutomski (Eds.). Dziecko w świecieludziiprzedmiotów (pp. 92, 94, 100, 103, 105-106). Poznań: Zyski S-ka.

Schulz, R. T., Gautier, I., Klin, A., Fulbright, R., Anderson, A., Volkmar, F., Skudlarski, P., Lacadie, C., Cohen, D., \& Gore J. (2000). Abnormal ventral temporal cortical activity during face discrimination among individuals with autism and Asperger's syndrome. Archives of General Psychiatry, 57.

Senator, D. (2006). Przejawy autyzmu w pierwszym roku życia. Pediatria Polska, 2, 128.

Sherrod, L. R. (1981). Issues in cognitive-perceptual development: the special case of social stimuli.

In M. E. Lamb, \& L. R. Sherrod (Eds.). Infant social cognition. New York: Erlbaum.

Siegel, B. (1996). The world of the autistic children. Understanding and Treating Autistic Spectrum Disorders. New York: Oxford University Press.

Stone, W. L. (1997). Autism in infancy and early childhood. In D. J. Cohen, \& F. R. Volkmar (Eds.). Handbook of autism and pervasive developmental disorders. New York: Oxford University Press. Taylor, M. (2007). Rozwój poznania społecznego z perspektywy teorii umysłu. n B. Bokus, \& G. W. Shugar (Eds.). Psychologia języka dziecka. Osiagnięcia, nowe perspektywy (p. 290). Gdańsk: Gdańskie Wydawnictwo Psychologiczne.

Urbaniuk, J. (2009). To co niewidoczne dla oczu. Prozopagnozja w diagnozie dziecka ze spektrum zaburzeń autystycznych. In B. Winczura (Ed.). Autyzm. Na grani cyzrozumienia (p. 66). Kraków: Impuls.

Walker-Andrews, A. S. (1997). Infants' perception of expressive behaviors: Differentiation of multi-modal information. Psychological Bulletin, 121.

Walton, G. E., Bower, N. J. A., \& Bower, T. G. R. (1992). Recognition of familiar faces by newborns. Infant Behavior and Development, 15.

Wing, L. (2005). Związek między zespołom Aspergera i autyzmem Kannera. In U. Frith (Ed.). Autyzm i zespół Aspergera (p. 117). Warszawa: Wydawnictwo Lekarskie PZWL. 


\title{
Vaikų autistų akių kontakto ir tiesioginès sąveikos nepakankamumas socialiniuose santykiuose
}

\author{
Barbara Winczura \\ Vroclavo universitetas, Istorijos ir pedagogikos katedra, Pedagogikos institutas, \\ J. W. Dawida g. 1, 50-527 Vroclavas, Lenkija, basiawa@wp.pl
}

\section{Santrauka}

Pagal autizmo diagnostikos kriterijus problemų spektras apima vaiko socialinę raidą, bendravimą, suvaržyto elgesio modelius, veiklą ir interesų sritis. Tačiau didžiausių sunkumų nuo autizmo kenčiantys vaikai patiria dẻl santykių su kitais žmonèmis. Akių kontakto sutrikimai ir negebejjimas sutelkti dėmesio ị pašnekovo veidą yra dažniausi simptomai. Didžiausios kliūtys užmezgant socialinius ryšius yra akių kontakto vengimas, negalèjimas bendraujant žvelgti pašnekovui ị akis, negebejjimas interpretuoti pašnekovo žvilgsnyje slypinčios informacijos bei žvilgsniu perteikti savo jausmus, kaip ir nepakankamas žvilgsnio krypties svarbos supratimas ar mimika perteikiamos informacijos apsunkintas interpretavimas, taip pat ribotas emocijų ir pažistamų veidų atpažinimas. Kadangi vaikai autistai negali visiškai panaudoti per akių kontaktą gaunamos informacijos ir negeba nagrinèti veido išraiškos, tų vaikų patirtis labai susiaurèja. Šio straipsnio tikslas yra pateikti tyrimo rezultatus ir pastebejimus akcentuojant nepakankamą vaikų autistų akių kontaktą ir ribotą tiesioginę sąveiką socialiai bendraujant; taip pat atlikta šių sunkumų, lemiančių ribotas socialinių ryšių galimybes, analizè.

Esminiai žodžiai: vaikas autistas, akių kontaktas, tiesioginis bendravimas, socialiniai santykiai, socialinis bendravimas. 